\title{
The metabolism of nitrogen, calcium and phosphorus in undernourished children
}

\author{
7.* The effect of partial or complete replacement of rice in poor \\ vegetarian diets by pearl millet (Pennisetum typhoideum)
}
BY P. P. KURIEN, M. SWAMINATHAN AND V. SUBRAHMANYAN
Central Food Technological Research Institute, Mysore, India

$$
\text { (Received } 27 \text { September I960-Revised I6 fanuary I961) }
$$

Pearl millet is an important food grain consumed widely as a staple food by poor people in different parts of India (Patwardhan, 1952), but no metabolic studies have so far been reported with diets containing it. Further, in view of the acute shortage of rice in the country, the use of pearl millet as a partial substitute needs to be studied. This paper describes the results of investigations on the effect on the metabolism of nitrogen, calcium and phosphorus of replacing rice in a poor vegetarian diet partially or completely by pearl millet (Pennisetum typhoideum).

\section{EXPERIMENTAL}

The plan of the experiment and the analytical methods used were similar to those described by Kurien, Narayanarao, Swaminathan \& Subrahmanyan (1960) in their studies with kaffir-corn diets. The ages, heights and weights of the eight boys studied

Table I. Ages, heights and weights of the boys at the beginning of the experiment

$\begin{array}{cccc}\begin{array}{c}\text { Child } \\ \text { no. }\end{array} & \begin{array}{c}\text { Age } \\ \text { (years) }\end{array} & \begin{array}{c}\text { Height } \\ \text { (cm) }\end{array} & \begin{array}{c}\text { Weight } \\ \text { (kg) }\end{array} \\ \text { I } & \text { I2 } & 142 & 31^{\circ} \cdot \\ 2 & 12 & 138 & 30^{\circ} 5 \\ 3 & \text { I2 } & 137 & 29 \cdot 6 \\ 4 & \text { II } & 137 & 28 \cdot 2 \\ 5 & \text { I } & 137 & 27 \cdot 8 \\ 6 & \text { I2 } & 132 & 26 \cdot 9 \\ 7 & \text { II } & 135 & 25 \cdot 5 \\ 8 & \text { II } & 132 & 23 \cdot 7\end{array}$

are given in Table $\mathrm{I}$. They were poor-class children living in a boarding home in Mysore City. The composition of the rice and pearl millet used is given in Table 2.

The mean daily intake $(\mathrm{g})$ of the cereals by the children was:

$\begin{array}{lcccc}\text { Cereal } & \text { Rice diet } & \begin{array}{c}\text { 25\% pearl- } \\ \text { millet diet }\end{array} & \begin{array}{c}50 \% \text { pearl- } \\ \text { millet diet }\end{array} & \begin{array}{c}\text { Pearl-millet } \\ \text { diet }\end{array} \\ \text { Rice } & 360 & 270 & 180 & - \\ \text { Pearl millet } & - & 90 & 180 & 360\end{array}$

* Paper no. 6: Brit. F. Nutr. (1960), 14, 339. 
The rest of their diet was the same as in the previous test (Kurien et al. 1960); the feeding procedure and collection of excreta were similar. Total N, Ca and P in food, urine and faeces were determined by the methods of Murthy, Swaminathan \& Subrahmanyan (1954).

\section{RESULTS AND DISCUSSION}

Pearl millet, like kaffir corn, contains fairly large amounts $(9 \circ \%)$ of roughage, i.e. cellulose and hemicelluloses. The mean daily faecal bulk increased with the amount of pearl millet in the diet. Similar observations have been reported earlier with diets based on ragi (Joseph, Kurien, Swaminathan \& Subrahmanyan, 1959) and kaffir corn (Kurien et al. 1960).

Table 2. Percentage composition of the raw milled rice and pearl millet

(Pennisetum typhoideum) used

\begin{tabular}{|c|c|c|}
\hline & $\begin{array}{l}\text { Raw milled } \\
\text { rice }\end{array}$ & $\begin{array}{l}\text { Pearl } \\
\text { millet }\end{array}$ \\
\hline Moisture & $10 \cdot \mathrm{I}$ & $12 \cdot 2$ \\
\hline Protein $(N \times 6.25)$ & 7.9 & I I. 3 \\
\hline Fat (ether extractives) & 0.5 & 3.8 \\
\hline Ash & 0.5 & $\mathrm{I} \cdot 8$ \\
\hline Starch & $80 \cdot \mathrm{I}$ & $60 \cdot 7$ \\
\hline Total sugars & 0.3 & $\mathrm{I} \cdot 2$ \\
\hline Crude fibre & 0.2 & $3 \cdot 2$ \\
\hline $\begin{array}{l}\text { Pentosans and other hemicelluloses } \\
\text { (by difference) }\end{array}$ & 0.4 & $5 \cdot 8$ \\
\hline Calcium & 0.012 & 0.046 \\
\hline Phosphorus & 0.142 & 0.314 \\
\hline Phytate phosphorus & 0.089 & 0.224 \\
\hline Calories (kcal/roo g) & 358 & 327 \\
\hline
\end{tabular}

Table 3. Mean daily intake, excretion and balance of nitrogen of the boys on the different diets

\begin{tabular}{|c|c|c|c|c|c|c|c|}
\hline \multicolumn{2}{|l|}{ Diet } & \multirow{3}{*}{$\begin{array}{l}\text { Intake } \\
(\mathrm{g})\end{array}$} & \multirow{2}{*}{\multicolumn{3}{|c|}{ Excretion $(\mathrm{g})$}} & \multirow{3}{*}{$\begin{array}{l}\text { Apparent } \\
\text { digesti- } \\
\text { bility } \\
\text { coeffi- } \\
\text { cient }(\%)\end{array}$} & \multirow{3}{*}{$\begin{array}{l}\text { Balance } \\
\text { (g) }\end{array}$} \\
\hline \multirow[b]{2}{*}{ Description } & \multirow{2}{*}{$\begin{array}{c}\text { Calorie } \\
\text { value } \\
\text { (kcal/day) }\end{array}$} & & & & & & \\
\hline & & & Faecal & Urinary & Total & & \\
\hline \multirow{4}{*}{$\begin{array}{l}\text { Rice } \\
25 \% \text { pearl millet } \\
50 \% \text { pearl millet } \\
\text { Pearl millet }\end{array}$} & I 86 I & $6 \cdot 92$ & $\mathrm{I} \cdot 7 \mathrm{r}$ & 3.19 & 4.90 & $75 \cdot 3$ & +2.02 \\
\hline & I 829 & $7 \cdot 26$ & $1 \cdot 95$ & $3 \cdot 44$ & 5.39 & $73 \cdot \mathrm{I}$ & +1.87 \\
\hline & 1802 & $7 \cdot 83$ & $2 \cdot 79$ & 3.55 & 6.34 & $64 \cdot 4$ & $+1 \cdot 49$ \\
\hline & $174 \mathrm{I}$ & $8 \cdot 67$ & 4.08 & $3 \cdot 4^{8}$ & 7.56 & $52 \cdot 9$ & $+I \cdot I I$ \\
\hline \multicolumn{7}{|c|}{ Standard error of the mean (2I D.F.) $\pm I^{*} 40$} & \pm 0.09 \\
\hline
\end{tabular}

Nitrogen (Table 3). The mean daily protein $(\mathrm{N} \times 6.25)$ intake on the different diets ranged from 43 to $54 \mathrm{~g}$. All the children were in positive $\mathrm{N}$ balance. The mean apparent digestibility of the proteins in the diet and the mean retention of $\mathrm{N}$ progressively decreased as the amount of pearl millet in the diet was increased.

Calcium (Table 4). The mean daily intake on the different diets ranged from 0.35 to $0.48 \mathrm{~g}$. All the children were in positive balance. The mean daily retention decreased as the amount of pearl millet in the diet was increased; this effect may have been due to the increased amount of phytate $\mathrm{P}$ in the diet. 
Phosphorus (Table 4). The mean intake on the different diets ranged from 0.73 to $1.35 \mathrm{~g}$. A large part $(48-60 \%)$ of the $\mathrm{P}$ in the diet was in the form of phytate $\mathrm{P}$. The mean daily retention of $\mathrm{P}$ ranged from 0.16 to $0.36 \mathrm{~g}$. Both intake and retention increased as the amount of pearl millet in the diet increased.

Table 4. Mean daily intake, excretion and balance of calcium and phosphorus of boys on the different diets

\begin{tabular}{|c|c|c|c|c|c|c|}
\hline \multirow[b]{2}{*}{ Description } & \multirow{2}{*}{$\begin{array}{l}\text { Calorie value } \\
\text { (kcal/day) }\end{array}$} & \multicolumn{4}{|c|}{ Excretion (mg) } & \multirow{2}{*}{$\begin{array}{c}\text { Balance } \\
(\mathrm{mg})\end{array}$} \\
\hline & & $\begin{array}{c}\text { Intake } \\
(\mathrm{mg})\end{array}$ & Faecal & Urinary & Total & \\
\hline \multicolumn{7}{|c|}{ Calcium } \\
\hline Rice & I86 I & 352 & 178 & 55 & 233 & +119 \\
\hline $25 \%$ pearl millet & 1829 & 378 & 212 & 49 & 261 & +117 \\
\hline $50 \%$ pearl millet & 1802 & 418 & 250 & 55 & 305 & $+1 I_{3}$ \\
\hline Pearl millet & $\mathrm{I} 74 \mathrm{I}$ & 479 & 333 & 54 & 387 & +92 \\
\hline \multicolumn{6}{|c|}{ Standard error of the mean (2 I D.F.) } & $\pm \quad 6.8$ \\
\hline \multicolumn{7}{|c|}{ Phosphorus } \\
\hline Rice & I 861 & 726 & 274 & 290 & 564 & +162 \\
\hline $25 \%$ pearl millet & 1829 & 867 & 359 & 284 & 643 & +224 \\
\hline $50 \%$ pearl millet & I 802 & 1029 & 468 & 264 & 732 & +297 \\
\hline Pearl millet & $174 \mathrm{I}$ & 1346 & 704 & 286 & 990 & +356 \\
\hline \multicolumn{6}{|c|}{ Standard error of the mean (2I D.F.) } & \pm 12.9 \\
\hline
\end{tabular}

\section{SUMMARY}

I. The effect on nitrogen, calcium and phosphorus metabolism of replacing $25 \%$, $50 \%$ or all of the rice in a poor vegetarian diet by pearl millet (Pennisetum typhoideum) was studied in eight boys aged $\mathrm{I} \mathrm{I}-\mathrm{I} 2$ years.

2. The daily intake of $\mathrm{N}$ was nearly the same on the different diets. All the subjects were in positive balance. The apparent digestibility of the proteins and the mean daily retention of $\mathrm{N}$ decreased as the proportion of pearl millet in the diet increased.

3. Although the addition of pearl millet led to a higher $\mathrm{Ca}$ intake, the amount of $\mathrm{Ca}$ retained decreased as the proportion of pearl millet in the diet increased. All the subjects were in positive balance.

4. Both the intake and retention of $P$ increased as the proportion of pearl millet in the diet increased.

We are grateful to Mr A. N. Sankaran and Miss K. Indiramma for the statistical analysis of the results and to $\mathrm{Mr}$ V. A. Daniel for technical assistance.

\section{REFERENCES}

Joseph, K., Kurien, P. P., Swaminathan, M. \& Subrahmanyan, V. (1959). Brit. $\mathscr{F}$. Nutr. I3, 2 I3. Kurien, P. P., Narayanarao, M., Swaminathan, M. \& Subrahmanyan, V. (1960), Brit. F. Nutr. 14, 339. Murthy, H. B. N., Swaminathan, M. \& Subrahmanyan, V. (I954). Brit. F. Nutr. 8, I I.

Patwardhan, V. N. (1952). Nutrition in India. Bombay: Indian Journal of Medical Sciences. 